UDC 332.54

\title{
MANAGEMENT PRIORITIES OF LAND RESOURCES USE IN THE CONTEXT OF THE AIRPORTS AND THEIR INFRASTRUCTURE OPERATION
}

\section{Stetsyuk, $\mathrm{PhD}$ in Economics \\ L. Skrypnyk, graduate student National Aviation University}

The place and significance of land resources in the air transport functioning are researched. It is shown that in the questions of land use it is expedient to apply management approaches, which forms the preconditions for a broader understanding of the exploitation issues. The purpose and functions that are realized in the context of the aviation transport land use (operation) are investigated. Functions might be differentiated into general and specific ones that are oriented by criteria-characteristics.The complex of processes influencing of the land resources structure of the transport industry is investigated.

Key words: land resources of air transport, use, airport, infrastructure

\section{Formulation of the problem}

The sphere of natural resources is the basis that largely determines the features of economic activity, the placement of productive forces, the behavior of market actors. At the same time, in many cases the natural resources using is not determined by rationality. But on the contrary - such method the natural resources using damages both the resource and the environment.

This statement also applies to land resources, which are unique both in their value and place in ensuring the acceptable functioning of the state's economic system. Land resources play an important role in supporting of the transport infrastructure proper functioning. In general, we note that Ukraine, as a transit country, has a significant potential for the development of the transport network. In addition, with the intensification of the processes of globalization, this potential 
will increase. One of the success factors of these processes is the efficient functioning of the transport infrastructure, which is possible taking into account such an important basis, which are the land resources.

Land resources play an important role in the development of aviation transport. However, as current practice shows, resources are not used sufficiently effectively, which requires the development of principles and approaches to improve the situation.

\section{Analysis of the last scientific researches and publications}

After analysis of the issue developments, we must emphasize the fact that scientific researches and publications ought to be divided into two groups. There is the first group, which is the formation of a conceptual vision in the field of land use, and the second specific group, which is formed the field aviation transport land resources of. Among the scientific researches and publications of the first group might include developments by Y. Dorosh [5], O. Drebot [6], V. Galushko [4], A. Tretyak [13] etc. The works of these scientists form a basic idea of the peculiarities of the land resources using, determine their basic characteristics, form approaches and ways to improve the situation. At the same time, it ought to be noted that the second direction concerning the aviation transport land resources, due to its specificity, at the development stage. It is also possible to identify a number of studies, among which it is possible to enumerate the work of $\mathrm{O}$. Novakovskoy [9], N. Bondarchuk [2,3].

At the same time, the issues of management of the aviation transport land resources using from the view point of the modern management positions and research of a processes influencing complex of the structure of managerial priorities remain issues with little research. Accordingly, the purpose of the article is the definition of management approaches to the land resources using in aviation transport in the context of the operation of airports and their infrastructure.

\section{Presenting of the main material}

The legal aspect is very important at research of the main issue of the land resources using in the context of the airports operation and their infrastructure. 
According to the Land Code of Ukraine (Article 72), "land of air transport includes such land as airports, aerodromes, isolated buildings, helicopter stations, repair factories of civil aviation, service facilities that provide air transport" [8]. The Law of Ukraine «About Transport» [7] also observes a similar position.

According to the Air Code of Ukraine [10] "land of airports (airfields), are the land plots, which contain buildings, structures and equipment, also the land plots, which are necessary for the airport (aerodrome) operation and defined by the general plan." In addition, this document forms the understanding of the category, which is called "for aerodrome territory".

The Cabinet of Ministers of Ukraine's Resolution No. 126 of February 24, 2016 "On Approval of the State Target Program for the Development of Airports for the Period until 2023" [11] might improve the situation regarding the operation of land resources of aviation transport. Considerable attention of this program is paid to the development of the aviation transport infrastructure, which is associated with the land resources using.

Thus, the aviation transport land is the land with transport infrastructure, in the framework of which activities are carried out to support the operation and implementation of the goals of airports.

The features of the aviation transport land operation might be explored in the context of management theory, which may be understood as a "management system that ensures the successful functioning, conservation and development of the organization of national, ..., municipal, local level of management" [12, p. 20].

In general, we note that the formation of a management system might go in several ways. In particular, a perspective management system might combine both existing conservative approaches and innovative, which are based on the activation of new methods and management tools.

Structurally, the system for managing the land use aviation transport involves the allocation of two blocks - theoretical and applied. The first of them involves the formation of conceptual foundations of the management activities, the definition of its purpose, functions, which are taking into account the possibility of 
influencing factors that might significantly change these categories. The application block focuses on identifying possible tools for implementing goals and functions (figure.1).

We focus on the theoretical control unit opportunities. It is extremely important, because from the initial settings, the conceptual vision of the problem depends on the success of its solution. The basic position of this unit is the formation of a management purpose. The main idea for managing system for the land of aviation transport is ensuring the effective use of the land fund (disclosure of functions) and supporting of the airport's activities and develop its infrastructure.

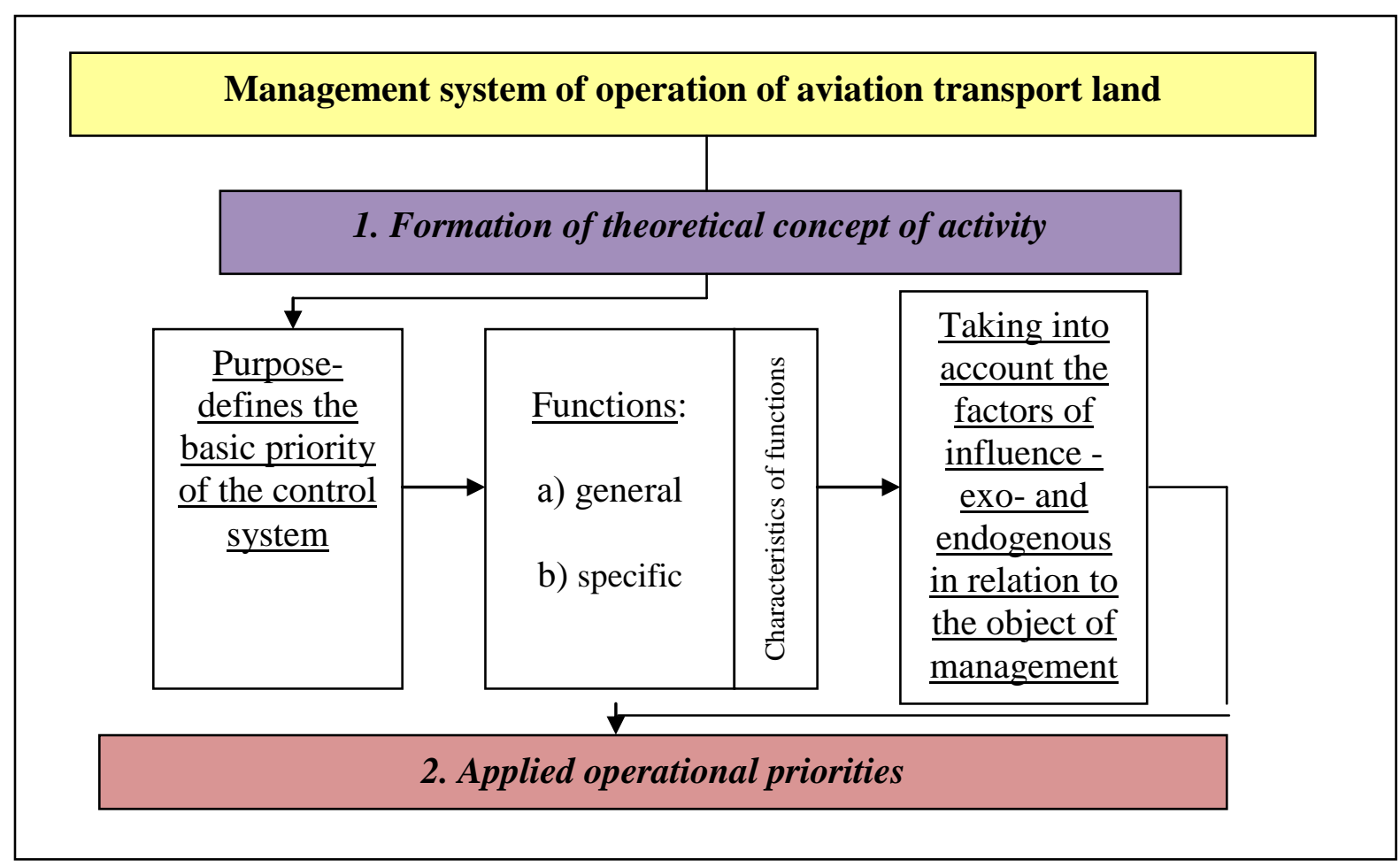
and its elements

Figure 1. Management system of operation of land of aviation transport

Within the theoretical block, we define a complex of tasks (functions) that are implemented in the context of the land use (operation) of aviation transport. Functions might be differentiated into general and specific.

a) General functions provide for consideration of the main transport lands objectives that they carry out. There are the main functions: 1. territorial basis for the placement of aviation transport structures; 2. supporting the functioning and 
implementation of the airport system and its infrastructure; 3. ensuring effective interaction between the components (elements) of the infrastructure; 4. ensuring the overall functioning of the transport infrastructure.

b) Specific functions are auxiliary to the general. These functions carry out an auxiliary role. There are the possibility of developing other activities (which do not related to aviation transport) and cooperation and stimulation of the innovative tools introduction.

Harmonious interaction between general and specific functions is important, because all these function have one idea and purpose. At the same time, it is possible to draw a clear line between them. The first ones carry out a complex of tasks of the basic, necessary, and the second ones are to a greater extent aim at finding additional sources of development.

Each of these functions might be determined by such characteristics as efficiency, adequacy, complexity, systemicity. The main purpose of using the function is the correction of a particular situation. Moreover, such actions might be determined by high qualitative characteristics and directed towards the ultimate purpose of influence. In addition, the important feature of the efficiency category is, as a statement which is indicated in the textbook [1], "displaying the relationship between the results, which have been obtained and the resources, which have been spent on their achievement."

Adequacy is the ability to act in accordance with the requirements and in accordance with high standards. Each function, which is used in the operation of aviation transport land, might be guided by these requirements. Adequacy provides an acceptable activity of management tools in the context of their impact on the phenomenon or process.

Complexity is the possibility of influence on related areas and activation of the function taken together of other, auxiliary, which will strengthen its influence and significance. It is an important feature of a function that takes into account the possibility of considering the implementation of a function, which are not as an individual influence, but as a broad-based instrument. 
System involves consideration of a specific function within a certain system, which is united by one direction, the nature of action, common features, etc. The introduction of such a characteristic is important in the study of processes that have several "exits" and "inputs", covering structures that are very remote from one another.

In addition to functions, management must take into account the system of influence factors, which might change the basic provisions of management. Influencing factors in relation to the control system are devided external and internal. Among external factors ones are distinguished such ones, which "circulate" outside of the control system. This is primarily economic, political and other factors. Internal factors are called such that are formed within both the processes of aviation transport land use and the management system in particular.

The reverse effect on the factors is probable, Given the strong interconnectedness of the factors of influence with the object of influence. Although this influence is not so powerful, but it also takes place. The action of these factors is also reflected during the selection of one or another mechanism of influence on the development of the complex.

The management system should provide for the functioning of a powerful monitoring service, which is formed an analysis and assess the basic parameters of the development of the aviation infrastructure complex in order to adequately react to the influence of factors and to correct their effect. These approaches might be done so that the actions are sound and consistent with the current development indicators.

Internal incentives for transformation are very important in order to implement these and other approaches, which will take part in the management system of aviation traffic operation. In our opinion, the motivation for transformational changes implies the ability of the structure itself to realize the need for change and to carry out a set of actions for their implementation. This path is more productive in terms of changing characteristics, as the transformation of the internal vision of change (on the basis of a real analysis of the state of the 
complex) takes place in the applied dimension of concrete actions. However, as a consequence of the impact of current realities, the structure of the complex does not feel the need for self-change.

Conclusions. It is expedient to study the peculiarities of operation of aviation transport land in the context of the management theory, which forms the preconditions for a broader understanding of the issues of operation. The system of operation management of aviation transport land involves the allocation of two blocks - theoretical and applied. The first of them involves the formation of the conceptual foundations of management activities, the definition of its purpose, functions, while are taking into account the possibility of influencing factors that might significantly change these categories. The second is the definition of possible tools for the realization of goals and functions. The purpose and functions of the control system are explored. It is shown that the functions might be general and specific and are guided by a number of characteristics. The emphasis is placed on the fact that the existence of internal incentives for transformation is important, for the implementation of these and other approaches to the management of the operation of land for aviation transport.

Directions of further researches: definition and detailing of functions with taking into account current trends of development, research of applied aspects of management, formation of ways and approaches of implementation of advanced western models of operation of land of aviation transport.

\section{References:}

1. Verkhovna Rada of Ukraine (2015), 232/94-вp, About transport, Law [232/94-вp.ZakonUkrainu Pro Transport], Verkhovna Rada of Ukraine, Kiev, Ukraine

2. Land Code of Ukraine dated October 25, 2001 № 2768-III // Database «Legislation of Ukraine» / The Verkhovna Rada of Ukraine. URL: http: // http://zakon2.rada.gov.ua/laws/show/2768-14 
3. Air Code of Ukraine dated May 19, 2011 No. 3393-VI // Database «Legislation of Ukraine» / The Verkhovna Rada of Ukraine. URL: http: // http://zakon3.rada.gov.ua/laws/show/3393-17

4. The Cabinet of Ministers of Ukraine (2016), 126-2016-п. Pro zatverdzhennya Derzhavnoyi tsil $\square$ ovoyi prohramy rozvytku aeroportiv na period do 2023 roku, Resolution [On approval of the state target program for the development of airports for the period up to 2023], The Cabinet of Ministers of Ukraine, Kiev, Ukraine

5. Andriychuk, M. (2002), Economics of agrarian enterprises. Additional. and processed 2nd form. [Ekonomika ahrarnykh pidpryyemstv. 2-he vyd., dop. i pereroblene], KNEU, Kiev, 624 p.

6. Bondarchuk N.V., (2009), "Concept and characteristic of land of aviation transport and their legal regime" ["Ponyattya ta kharakterystyka zemel $\square$ aviatsiynoho transportu ta yikh pravovoho rezhymu "], State and Law, Issue 46, pp. 431-436

7. Bondarchuk, N. (2009), Concept and characteristics of land of aviation transport and their legal regime, Ph.D. Thesis, VM Koretsky National Academy of Sciences of Ukraine, Kiev, Ukraine, 181 p.

8. Galushko, V.P., Bilyk, Yu.D., Danilenko, A.S., (2006), A Formation of the land market in Ukraine [Formuvannya rynku zemli $\mathrm{v}$ Ukrayini], View "Harvest", Kiev, 278 p.

9. Dorosh Yosyp. Theoretical and Methodological Foundations of Land Relations in Ukraine [monograph] / VIPOL, Ukraine, Kiev, 2011.- 286 p.

10.Drebot O.I., Vysochanska M.Ya. (2014), “ Ecological and economic support of rational use of land resources of Ukraine " [" Ekoloho-ekonomichne zabezpechennya ratsional $\square$ noho vykorystannya zemel $\square$ nykh resursiv Ukrayiny ”], Tavricheskii Scientific Bulletin: Scientific Journal, No.88, pp. 268-274

11.Novakovskaya I.O., Skrypnyk L.R. (2017), “ Problems of classification and formation of land of aviation transport"["Problemy klasyfikatsiyi ta 
formuvannya zemel $\square$ aviatsiynoho transportu’'], Land management, inventory and land monitoring, No.3, pp. 45-46

12.Ukolov, V.F., Mass, A.M., Bystryakov, I.K., (2004), Management theory: study. for high schools [Teoriya upravleniya: ucheb. dlya vuzov [], ZAO Izdatelstvo "Ekonomika", 656 p.

13.Tertiak A.M., Theoretical and Methodological Foundations of Formation and Functioning [monograph]/ SPOL, Ukraine, Lviv, 201. - 520 p. 